\title{
The influence of hypothermia prevention by application of skin moisture absorbent on the value of body temperature, body weight and blood parameters in piglets
}

[A influência da prevenção da hipotermia pela aplicação de absorvente de umidade da pele no valor da temperatura corporal, peso corporal e parâmetros sanguíneos em leitões]

\author{
M. Mirkov (iD), I. Radović(D), M. Cincović(iD), M. P. Horvatović (iD), S. Dragin (iD \\ University of Novi Sad - Faculty of Agriculture - Department of Animal Science \\ Trg Dositeja Obradovića 8, 21000 Novi Sad, Serbia
}

\begin{abstract}
Reducing the mortality rate is of a great economic importance for pig farming. Therefore, it is necessary to define the conditions in the farrowing unit based on the performance of the piglets, and specific hematological and biochemical parameters. Therefore, the aim of this paper is to examine the importance of using skin moisture absorbent and its influence in preventing hypothermia, which causes great economic losses in pig production. The experiment was set up on a commercial farm in Serbia and included 92 pigs divided into the experimental and control group. Body temperature values, body weight and blood parameters were monitored. The obtained values indicate that there is a significantly positive correlation of body temperature change and body weight values, and body temperature showed a significantly higher increase in the experimental group compared to the control group. The results obtained from hematological and biochemical parameters provide a clearer picture of the metabolic processes in piglets in the farrowing unit and can be used to further improve pig production and as a complement to genetic enhancement.
\end{abstract}

Keywords: hematological parameters, biochemical parameters, hypothermia, piglets, moisture absorbent

\section{RESUMO}

A redução da taxa de mortalidade é de grande importância econômica para a suinocultura. Portanto, é necessário definir as condições na unidade de parto com base no desempenho dos leitões, para serem parâmetros hematológicos e bioquímicos específicos. Portanto, o objetivo deste trabalho é examinar a importância do uso de absorvente de umidade na pele e sua influência na prevenção da hipotermia, que causa grandes perdas econômicas na produção de suínos. A experiência foi montada em uma fazenda comercial na Sérvia, e incluiu 92 porcos divididos no grupo experimental e de controle. Os valores de temperatura corporal, pesos corporais e parâmetros sanguíneos foram monitorados. Os valores obtidos indicam que existe uma correlação significativamente positiva entre os valores da temperatura corporal e dos pesos corporais, e a temperatura corporal mostrou um aumento significativamente maior no grupo experimental em comparação com o grupo de controle. Os resultados obtidos a partir de parâmetros hematológicos e bioquímicos fornecem uma imagem mais clara dos processos metabólicos em leitões na unidade de parto e podem ser usados para melhorar ainda mais a produção de suínos e como um complemento ao melhoramento genético.

Palavras-chave: parâmetros hematológicos, parâmetros bioquímicos, hipotermia, leitões, absorvente de umidade

\section{INTRODUCTION}

For years the selection direction in pig production has been focused on increasing litter size. Ruthereford et al. (2013) state that the increase in the number of piglets per litter has gone from 0.16 to 0.5 piglets per year since 1996 . Increasing litter size in production has caused problems with farrowing length (Lay Jr et al., 2002), rupture of the umbilical cord in unborn piglets due to prolonged and difficult farrowing (Panzardi et al., 2013; Lay Jr et al., 2002), reduction of 
thermoregulatory capacity in piglets (Berg et al., 2006), decreased muscular energy production (Rowland et al., 2014), while Staarvik et al. (2019) point out that piglets are born with little physiological ability to produce glucose in the first hours after birth, and other problems.

Piglets at birth have to deal with unfavorable environmental conditions, as they do not have the natural protection for external conditions as young offspring of some other species of animals, and also the genetic potential is not fully adapted to farm conditions. To mitigate these deficiencies, farmers try to dry the piglets by wiping or using a skin-dryer preparation. Andersen et al., (2009) state that drying piglets at birth can result in reduced mortality.

The role of skin dryers in piglets is to help piglets cope with changing the environment more easily, to suck up colostrum in a timely manner and to suck in an adequate amount of colostrum, to prevent hypothermia.

Hypothermia attracts a lot of attention in pig farming because it represents a major economic loss that is difficult to cope with. There are no medicines or vaccines for hypothermia. Prevention should, as a rule, cover many production aspects in order to reduce the effects of hypothermia. An important aspect in preventing hypothermia is preventive measures that reduce the risk of hypothermia occurrence or to reduce the effects of hypothermia. Caldara et al. (2014) point out that hypothermia is a major cause of neonatal mortality. Hypoxia can also significantly affect the prolongation of time from birth to first suckling, which can result in the appearance of hypothermia and hypoglycemia (Panzardi et al., 2013).

The body attempts to cope with hypothermia through the cardiovascular system by activating peripheral vasoconstriction, sinus bradycardia with prolonged QT intervals, thinned heart rate, decreased ejection fraction, and minute volume (Steen et al., 1979), and Groban et al. (2002) state that a more severe form of hypothermia $\left(<30^{\circ} \mathrm{C}\right)$ results in a reduction of myocardial contractions. According to Malmkvist et al. (2012) mechanisms for preserving heat in newborns are piloreaction and peripheral vasoconstriction. Baxter et al. (2008) state that piglets with low body temperature are difficult to adapt to changes in temperature at birth, affecting homeothermic equilibrium. Hypothermia results in poor piglet mobility, which affects colostrum intake or struggling among each other to reach the glands. (Lay Jr et al., 2002; Herpin et al., 1996), and Vallet and Miles (2012) state that smaller piglets are weaker due to decreased cerebral myelination due to slower transmission of nerve impulse.

The main objective of the presented study is to show the effect of the moisture absorbent (Mistral@) used and to examine their effect in preventing hypothermia on body temperature, body weights and blood parameters in piglets.

\section{MATERIALS AND METHODS}

The research was carried out on a farm in Vojvodina with a capacity of 1,700 sows. The farm has a complete production cycle from sows to fatteners and the farm does the selection of pure breeds to produce F1 gilts. The study included piglets obtained from $\mathrm{F} 1$ generation sows (Yorkshire x Landras and Landras x Yorkshire) from the second to the 8th parities. 92 pigs (41 pigs from the control group and 51 pigs from the experimental group) participated in the experiment. The sows in the model were fed the same diet, and the sows that were treated, their piglets were not included in the experiment. The pigs from the experimental group were treated with the piglet skin dry preparation at birth, after which they were marked with plastic ear tags, after which the body weight and body temperature were measured.

Body weight measured at birth, 3h, 24h, 16, 25, 40 days of age. Body temperature measured by thermometer, $320 \times 240$ heat camera and IC thermometer were measured at birth, $3 \mathrm{~h}$ and $24 \mathrm{~h}$ after birth.

Blood was taken into EDTA vacuum tubes from the jugularis externa (regio colli lateralis) vein, three days after birth and sent to the laboratory for $2 \mathrm{~h}$ after sampling, after which they were immediately processed in the laboratory.

Hematological analyzes: Hematological analyzes were performed on a NIHON KOHDEN analyzer (Japan) with pig blood analysis software. A standard blood count was determined.

Biochemical analyzes: Blood glucose, total protein, albumin, globulin, cholesterol, 
triglyceride, total bilirubin, AST, ALT, urea, alpha amylase and lipase were determined using standard Byosystem kits (Spain) using a Chemray-Rayto analyzer (China).

Differences in body temperature, body weight, and blood parameters between the experimental and control groups were examined by t-test to compare the mean value of the independent samples. The correlation between different methods for measuring body temperature in piglets was determined by statistical analysis of Pearson's correlation coefficient. The correlation between dynamic changes in body temperature and body weight in piglets in the first $24 \mathrm{~h}$ of life was determined by regression linear analysis. It was determined by partial correlation analysis whether dynamic change in body temperature (24$0 \mathrm{~h}$ ) was a factor controlling the linear relationship between dynamic change in body weight and total protein concentration. Statistical package SPSS (IBM, 2017) was used.

\section{RESULTS}

In piglets in the experimental group at birth (Table 1a), a lower rectal body temperature was found and a tendency towards lower values measured by the heat and IC thermometer, $3 \mathrm{~h}$ after birth there was still lower body temperature in the experimental piglet group, whereas the difference in temperature measured by IC thermometer and heat camera was not statistically significant (NS). No statistically significant differences were found between the experimental and control groups 24 hours after birth. Examination of dynamic changes in body temperature values expressed as a difference (0-24h) showed that body temperature showed a significant increase in the experimental compared to the control group of piglets, regardless of the method of measurement.

Table 1a. The values of observed parameters and t test between the experimental and control group

\begin{tabular}{lccc}
\hline Parameters & experimental & control & $\mathrm{p}$ \\
\hline \multicolumn{3}{c}{ Body temperature } \\
\hline Rectal 0h & $34.1 \pm 1.45$ & $35.8 \pm 1.21$ & $<0.001$ \\
Heat camera 0h & $34.7 \pm 1.89$ & $36.02 \pm 1.74$ & $<0.1$ \\
IC thermometer 0h & $31.6 \pm 1.83$ & $32.8 \pm 1.58$ & $<0.1$ \\
Rectal 3h & $36.12 \pm 1.37$ & $36.97 \pm 0.95$ & $<0.01$ \\
Heat camera 3h & $37.15 \pm 1.89$ & $37.6 \pm 1.74$ & $\mathrm{NS}$ \\
IC thermometer 3h & $33.46 \pm 1.41$ & $33.67 \pm 1.42$ & $\mathrm{NS}$ \\
Rectal 24h & $36.8 \pm 0.89$ & $37.1 \pm 0.92$ & $\mathrm{NS}$ \\
Heat camera 24h & $37.05 \pm 0.96$ & $37.02 \pm 1.09$ & $\mathrm{NS}$ \\
IC thermometer 24h & $33.77 \pm 0.74$ & $33.38 \pm 0.99$ & $<0.1$ \\
Rectal 0-24h & $2.69 \pm 0.30$ & $1.32 \pm 0.22$ & $<0.001$ \\
Heat camera 0-24h & $2.31 \pm 0.28$ & $1.01 \pm 0.26$ & $<0.001$ \\
IC thermometer 0-24h & $2.02 \pm 0.19$ & $0.55 \pm 0.1$ & $<0.001$ \\
\hline
\end{tabular}

The body weight of the experimental group was lower at birth, so that in the later test period the difference in body weight between the experimental and control group was lost. In the piglets of the experimental group there was a significantly higher weight gain in the first 24 hours compared to the control group of the piglets, while on day 40 there was no statistically significant difference between body weights (Table 1b).

Observed blood values indicate that there are highly significant differences $(p<0.01)$ between the parameters of the experimental and control groups in mean corpuscular hemoglobin concentration, aspartat, cholesterol, total protein, globulin and lipase, while the significance level p $<0.05$ was determined among the following parameters: white blood cell, glucose, albumin. Significance level $\mathrm{p}<0.1$ was recorded for urea parameter, while statistical significance (NS) was not determined for red blood cell, hemoglobin, hematocrit, mean corpuscular volume, mean corpuscular hemoglobin, triglyceride, alanine aminotransferase, alpha amylase, total bilirubin parameters. The White blood cell concentration is lower in piglets from the experimental group, which may indicate that the organism does not need to produce higher white blood cell concentrations and that the ambient pressure that pathogens can create is significantly lower compared to white blood cell piglets from the 
control group. The experimental group is also characterized by a lower concentration of AST, which is often used to detect liver damage. Glucose concentration was increased in piglets of the experimental group, which is desirable because it is important for piglets in the first days of life. The increased concentration of total protein was also expected in piglets from the experimental group, because the concentrations of albumin and globulin were also increased. The lipase concentration was significantly lower in the control group compared to the experimental group $(68.8 \pm 13.8 ; 84.19 \pm 12.8)$. The results are shown in Table 1c.

Table $1 \mathrm{~b}$. The values of observed parameters and $\mathrm{t}$ test between the experimental and control group

\begin{tabular}{lccc}
\hline Parameters & experimental & control & $\mathrm{p}$ \\
\hline BW 0h & Body weight & & \\
BW 3h & $1.28 \pm 0.34$ & $147 \pm 0.31$ & $<0.05$ \\
BW 24h & $1.36 \pm 0.33$ & $1.35 \pm 0.28$ & $\mathrm{NS}$ \\
BW 16 days & $1.52 \pm 0.3$ & $1.55 \pm 0.31$ & $\mathrm{NS}$ \\
BW 25days & $4.93 \pm 1.13$ & $4.70 \pm 0.92$ & $\mathrm{NS}$ \\
BW 40 days & $6.96 \pm 1.3$ & $6.7 \pm 1.51$ & $\mathrm{NS}$ \\
Differences BW 0-24h & $9.25 \pm 1.46$ & $9.55 \pm 1.87$ & $\mathrm{NS}$ \\
Differences BW 0h-40 day & $0.23 \pm 0.05$ & $0.07 \pm 0.02$ & $<0.001$ \\
\hline
\end{tabular}

BW-body weight

Table 1c. The values of observed parameters and t test between the experimental and control group

\begin{tabular}{lccc}
\hline Parameters & experimental & control & $\mathrm{p}$ \\
\hline & Blood parameters & & $<0.05$ \\
WBC- white blood cell & $9.85 \pm 3.76$ & $12.69 \pm 6.04$ & $\mathrm{NS}$ \\
RBC- red blood cell & $3.76 \pm 0.7$ & $4.04 \pm 0.78$ & $\mathrm{NS}$ \\
HGB- hemoglobin & $74.5 \pm 16.6$ & $75.94 \pm 16.59$ & $\mathrm{NS}$ \\
HCT- hematocrit & $25.33 \pm 4.44$ & $25.52 \pm 4.83$ & $\mathrm{NS}$ \\
MCV- mean corpuscular volume & $65.68 \pm 3.76$ & $64.67 \pm 2.66$ & $\mathrm{NS}$ \\
MCH- mean corpuscular hemoglobin & $21.92 \pm 1.7$ & $20.97 \pm 3.8$ & $<0.01$ \\
MCHC- mean corpuscular hemoglobin & $332 \pm 17.5$ & $316 \pm 15.4$ & $<0.01$ \\
concentration & & & $\mathrm{NS}$ \\
AST- aspartat & $76 \pm 27$ & $102 \pm 51$ & $<0.01$ \\
Triglyceride & $1.87 \pm 0.71$ & $1.58 \pm 0.89$ & $\mathrm{NS}$ \\
Cholesterol & $2.20 \pm 0.48$ & $2.94 \pm 0.61$ & $<0.05$ \\
ALT- -alanine aminotransferase & $77 \pm 19.1$ & $89 \pm 53.2$ & $<0.01$ \\
Glucose & $6.27 \pm 1.5$ & $5.55 \pm 1.19$ & $<0.1$ \\
Total protein & $60.4 \pm 7.7$ & $53.8 \pm 9.8$ & $\mathrm{NS}$ \\
Urea & $4.4 \pm 2.2$ & $3.3 \pm 2.3$ & $<0.05$ \\
Alpha Amylase & $944 \pm 180$ & $951 \pm 255$ & $<0.01$ \\
Albumin & $15.1 \pm 2.85$ & $13.2 \pm 4.28$ & $<0.01$ \\
Globulin & $45.3 \pm 6.8$ & $40.6 \pm 7.7$ & $\mathrm{NS}$ \\
Lipase & $84.19 \pm 12.8$ & $68.8 \pm 13.8$ & $42.9 \pm 26.8$ \\
BTCC - Total bilirubin & $38.4 \pm 16.18$ & & \\
\hline
\end{tabular}

Correlation analysis between body temperature values measured in three ways shows that there is a high correlation between measured values within the same measurement day, but not within different measurement days (Table 2). 
Table 2. Correlation matrix between different measurement methods of body temperature

\begin{tabular}{|c|c|c|c|c|c|c|c|c|c|c|}
\hline & & Rectal0h & Heatc0h & ICth $0 \mathrm{~h}$ & Rectal3h & Heatc3h & ICtth3h & Rectal24h & Heatc24h & ICth24h \\
\hline \multirow{2}{*}{ Rectal0h } & $\mathrm{R}$ & 1 & & & & & & & & \\
\hline & $\mathrm{p}$ & & & & & & & & & \\
\hline \multirow[t]{2}{*}{ Heatc0h } & $\mathrm{R}$ & $0.366^{* *}$ & 1 & & & & & & & \\
\hline & $\mathrm{p}$ & 0.002 & & & & & & & & \\
\hline \multirow[t]{2}{*}{ ICth0h } & $\mathrm{R}$ & $0.486^{* *}$ & $0.612^{* *}$ & 1 & & & & & & \\
\hline & $\mathrm{p}$ & 0.000 & 0.000 & & & & & & & \\
\hline \multirow[t]{2}{*}{ Rectal3h } & $\mathrm{R}$ & $0.304^{* *}$ & $0.336^{* *}$ & $0.344^{* *}$ & 1 & & & & & \\
\hline & $\mathrm{p}$ & 0.009 & 0.004 & 0.003 & & & & & & \\
\hline \multirow[t]{2}{*}{ Heatc3h } & $\mathrm{R}$ & 0.223 & $0.288^{*}$ & $0.392^{* *}$ & $0.685^{* *}$ & 1 & & & & \\
\hline & $\mathrm{p}$ & 0.060 & 0.014 & 0.001 & 0.000 & & & & & \\
\hline \multirow[t]{2}{*}{ ICth3h } & $\mathrm{R}$ & 0.184 & $0.296^{*}$ & $0.399^{* *}$ & $0.559^{* *}$ & $0.862^{* *}$ & 1 & & & \\
\hline & $\mathrm{p}$ & 0.122 & 0.012 & 0.001 & 0.000 & 0.000 & & & & \\
\hline \multirow[t]{2}{*}{ Rectal24h } & $\mathrm{R}$ & 0.221 & 0.005 & 0.054 & $0.260^{*}$ & 0.134 & 0.133 & 1 & & \\
\hline & $\mathrm{p}$ & 0.063 & 0.969 & 0.651 & 0.028 & 0.260 & 0.265 & & & \\
\hline \multirow[t]{2}{*}{ Heatc24h } & $\mathrm{R}$ & 0.130 & 0.141 & $0.331^{* *}$ & $0.279^{*}$ & $0.388^{* *}$ & $0.417^{* *}$ & $0.324^{* *}$ & 1 & \\
\hline & $\mathrm{p}$ & 0.276 & 0.237 & 0.004 & 0.018 & 0.001 & 0.000 & 0.005 & & \\
\hline \multirow[t]{2}{*}{ ICth24h } & $\mathrm{R}$ & -0.033 & -0.054 & 0.046 & 0.094 & $0.323^{* *}$ & $0.350^{* *}$ & $0.239^{*}$ & $0.642^{* *}$ & 1 \\
\hline & $\mathrm{p}$ & 0.781 & 0.652 & 0.701 & 0.430 & 0.006 & 0.003 & 0.043 & 0.000 & \\
\hline
\end{tabular}

Rectal 0h: measured by thermometer (rectal temperature) at birth; Heatc 0h: measured by heat camera at birth; ICth 0h: measured by IC thermometer at birth;

Rectal 3h: measured by thermometer (rectal temperature) 3h after birth; Heatc 3h: measured by heat camera $3 \mathrm{~h}$ after birth; ICth $3 \mathrm{~h}$ : measured by IC thermometer $3 \mathrm{~h}$ after birth;

Rectal 24h: measured by thermometer (rectal temperature) $24 \mathrm{~h}$ after birth; Heatc $24 \mathrm{~h}$ : measured by heat camera $24 \mathrm{~h}$ after birth; ICth 24h: measured by IC thermometer $24 \mathrm{~h}$ after birth

Dynamic changes in body temperature are in significantly positive correlation with dynamic changes in body weight (change $24 \mathrm{~h}$ at birth versus $0 \mathrm{~h}$ at birth) (Chart 1).

The correlation between total protein and increase of gain is controlled by the achieved difference in body temperature (Chart 2), correlation when excluding the influence of body temperature notice that the regression line tends to zero (graph 3 ). Dynamic changes in body temperature are a controlling factor which controls the correlation between total protein concentration and dynamic changes in body weight in the first 24 hours after birth.

\section{DISCUSSION}

The piglets from the experimental group had a lower body temperature in all three measurement methods compared to the control group at birth, $3 \mathrm{~h}$ after birth, while the average values were approximately the same $24 \mathrm{~h}$ after birth in both groups. Moreira et al. (2016) state that the piglet body temperature immediately after birth is $37.0 \pm 0.10^{\circ} \mathrm{C}$, which is closest to the body temperature measured by the heat camera in piglets from the control group, which is $36.2 \pm 1.74$.

Due to the underdeveloped piglet thermoregulation system, even small differences in temperature can be harmful to piglets as indicated by Sahuquillo and Vilalta (2007) and Gunn et al. (2017) who, by measuring the forehead temperature, found that a decrease in $1 \mathrm{C}$ temperature can lead to a decrease in metabolic rate by $7-9 \%$, a decrease in oxygen utilization and $\mathrm{CO} 2$ production due to hypothermia. Tuchscherer et al. (2000) and Casellas et al. (2004) examining piglet body temperature indicate that rectal temperature measured $1 \mathrm{~h}$ after farrowing is largely variable trait and that better insight into thermoregulatory capacity is obtained by measuring rectal temperature within $24 \mathrm{~h}$ of farrowing, according to Baxter et al. (2008) rectal temperature $2 \mathrm{~h}$ after birth is a good indicator of thermoregulatory success. 


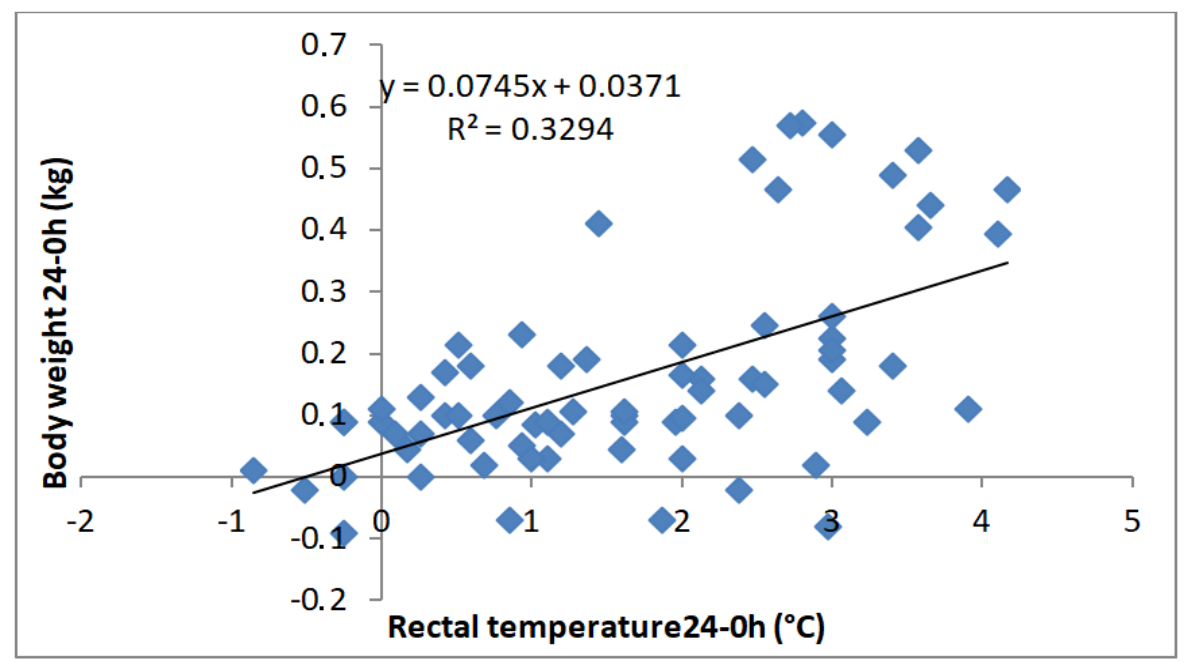

Chart 1 . Trend of body weight movement in the first 24 hours after birth in relation to rectal temperature in the first 24 hours after birth (regression analysis)

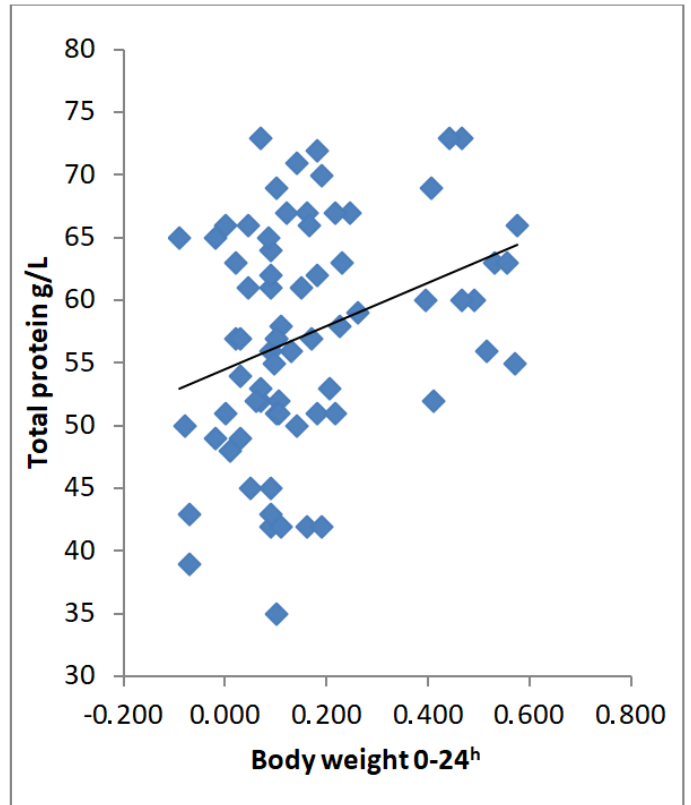

Chart 2. The correlation between total protein and body weight (0-24 hours)

The calculated regression coefficient indicates that the average body weight of the piglets in the first 24 hours of life increases by $0.0745 \mathrm{~kg}$ with an increase in one degree of rectal temperature. Berthon et al. (1993) and Herpin et al. (1994) point out that piglets achieve thermal homeostasis $24 \mathrm{~h}$ after birth at a body temperature of $38-39^{\circ} \mathrm{C}$, and Moreira et al. (2016) state that the average body temperature of piglets $24 \mathrm{~h}$ after birth is 38.6 $\pm 0.04{ }^{\circ}$ C. Herpin et al. (2002) state that rectal temperature reaches a normal level of $39^{\circ} \mathrm{C}$

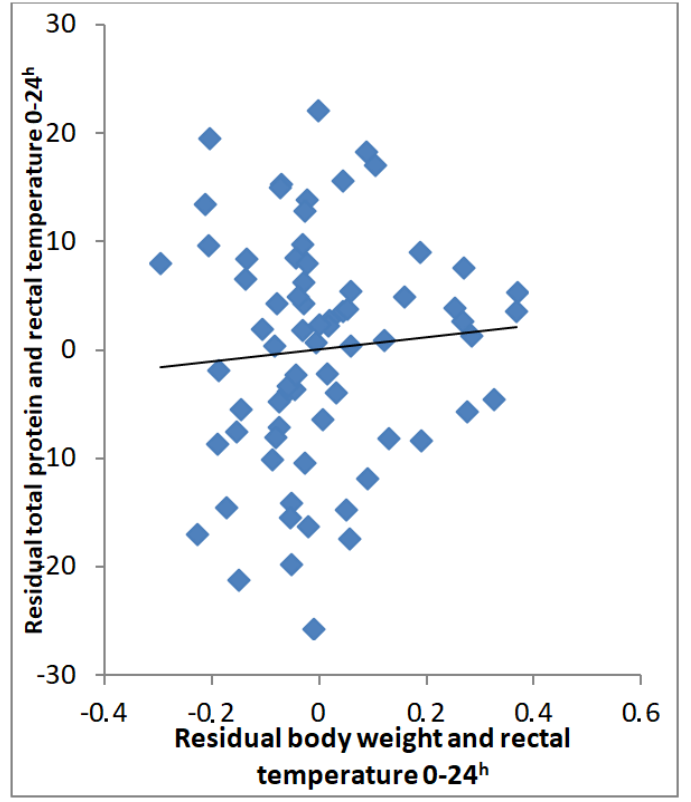

Chart 3. Correlation view when influence of body temperature was excluded

within $48 \mathrm{~h}$ of birth, whereas piglets with a lower rectal temperature $24 \mathrm{~h}$ after farrowing have poorer thermoregulatory capacity (Muns et al., 2013; Panzardi et al., 2013). Reasons for body temperature variability is as Panzardi et al. (2013) point out that body temperature $24 \mathrm{~h}$ after birth is associated with birth weight of piglets $(r=0.35)$ and that $46 \%$ of piglets of birth weight $<1275 \mathrm{~g}$ have a temperature below $38.1 \mathrm{oC}$, compared to $17 \%$ of piglets weight $\geq 1275 \mathrm{~g}$. Muns et al. (2015) state that body weight is an indicator of 
thermoregulatory capacity, and Kammersgaard et al. (2011) associate low rectal temperature $2 \mathrm{~h}$ after farrowing with lower body weight. Decreases in body temperature are often caused by decreased locomotor activity and due to imbalances in gas exchange, acid base balance and energy metabolism, which consequently occur with prolongation of farrowing time and more commonly occur in pigs that were last farrowed (Orozco-Gregorio et al., 2010; Baxter et al., 2008).

Fetal glucose levels are maintained by transplacental maternal glucose transfer, while this transfer is abolished after birth whereby piglets rely on their own quantities, which is a critical period in piglet life and a reason for monitoring blood parameters in piglets. González-Lozano et al. (2009) and Mota-Rojas et al. (2015) state that for better estimation of neonatal survival rate it is necessary to evaluate the physiological and metabolic profiles of piglets, because according to Staarvik et al. (2019) piglets are not physiologically capable of producing sufficient glucose to maintain normal glycemia in the first hours after birth.

The analysis of blood parameters aimed to examine the correlation between blood parameters in assessing the health and productivity of piglets, since immediately after birth piglets rely on glycogen reserves and colostrum intake to preserve the presence of normal blood glucose. On the third day of birth, glucose was higher in piglets treated with a skindry preparation as opposed to control group.

According to Trayhurn et al. (1989) and Herpin et al. (2002) piglets are born with a small amount of brown adipose tissue, which according to Sjaastad et al. (2010) together with adipose tissue play an essential role in regulating body temperature. Soerensen and Pedersen (2015) point out that piglets are born with $2 \%$ and less body fat and that the amount does not increase in the first two weeks of life. As compensation for this physiological weakness, piglets attempt to replace heat production by shaking skeletal muscle, which requires glucose energy, which can be a problem as piglets are born with an immature mechanism of gluconeogenesis (Staarvik et al., 2019). The obtained results indicate that piglets from the experimental group produced a higher amount of energy in the first $24 \mathrm{~h}$ of life, but that they had higher blood glucose content on the third day compared to the control group. The difference in glucose and body temperature in the experimental and control groups can be attributed to the use of skin drying absorbents. The piglets of the experimental groups did not have to spend more energy on drying their skin and warming themselves, which resulted in an increase in body temperature and lower glucose consumption. Increased blood glucose levels of piglets born at the same time Trujilo-Ortega et al. (2007) associate with difficult farrowing which results in the mobilization of energy reserves to compensate hypoxia. Herpin et al. (1996) and MartínezRodríguez et al. (2011) explain that increased glucose concentration at birth is due to catecholamine release and stimulation of secondary liver glycogenolysis due to decreased oxygen content. Panzardi et al. (2013) point out that low (24-30 mg / dl) and high (45-162 mg / dl) blood glucose concentrations at birth are associated with higher mortality at 3-7 days after birth due to physiological exhaustion, and Baxter et al. (2008, 2009) state that blood glucose concentration $24 \mathrm{~h}$ after farrowing is a better indicator of survival than glucose concentration at birth.

Glucose concentration is a variable trait and can easily fall to the level of hypoglycemia $(<2.2$ mmol / 1) within 24-36h of birth if pigs do not reach tits for sucking colostrum (Staarvik et al., 2019). According to Theil et al. (2014) piglets are born with glycogen reserves sufficient for $16 \mathrm{~h}$ of life, and according to Staarvik et al. (2019) oneday-old piglets had an average glucose value of $5.48 \mathrm{mmol} / \mathrm{l}$ (standard deviation of $1.44 \mathrm{mmol} /$ 1), at a range of 1.2-10.6 mmol / 1 .

Total protein levels are used to assess nutritional status, as well as to monitor various diseases and disorders. Cabrera et al. (2012) note that IgG concentration is associated with a positive correlation with the concentration of total protein in pig blood. According to Kósa et al. (2019) recorded concentration of total proteins is $50 \pm$ $3.19 \mathrm{~g}$ and $51.39 \pm 21.29 \mathrm{~g}$. The same authors state that higher amounts of total protein occur as a consequence of improved gut function and increased food intake. Analysis of the partial correlation in the paper revealed that the body temperature (24-0h) is the influence that controls the linear relationship of the dynamic change of body weight and protein concentration, which can 
be seen in chart 2 , where it can be seen that the regression line tends to zero when the body temperature influence is excluded.

\section{CONCLUSION}

The use of Mistral ${ }^{\circledR}$ leads to a significant increase in body temperature in the first 24 hours after the birth of piglets. The increase of body temperature correlates positively with weight gain within the first 24 hours of birth. Mistral®-treated piglets show better glycemia and higher total protein level and protein fractions. The correlation between the concentration of total proteins and the change in body weight was controlled by the change in body temperature in the first 24 hours after the birth of piglets. The administration of Mistral ${ }^{\circledR}$ allows significant changes in body temperature, body weight and blood parameters in piglets within the first 24 hours of birth.

\section{ACKNOWLEDGEMENTS}

Research was financed by the Ministry of Education and Science Republic of Serbia, project TR 31081.

\section{REFERENCE}

ANDERSEN, I.L.; HAUKVIK, I.A.; BØE, K.E. Drying and warming immediately after birth may reduce piglet mortality in loose-housed sows. Animal, v.3, p.592-597, 2009.

BAXTER, E.M.; JARVIS, S.; D'EATH, R.B.; ROSS, D.W. et al. Investigating the behavioural and physiological indicators of neonatal survival in pigs. Theriogenology, v.69, p.773-783, 2008.

BAXTER, E.M.; JARVIS, S.; SHERWOOD, L.; ROBSON, S.K. et al. Indicators of piglet survival in an outdoor farrowing system. Livest. Sci., v.124, p.266276, 2009.

BERG, F.; GUSTAFSON, U.; ANDERSSON, L. The uncoupling protein 1 gene (UCP1) is disrupted in the pig lineage: a genetic explanation for poor thermoregulation in piglets. PLoS Genet., v.2, p.e129, 2006.

BERTHON, D.; HERPIN, P.; DUCHAMP, C.; DAUNCEY, M.J.; LE DIVIDICH, J. Modification of thermogenic capacity in neonatal pigs by changes in thyroid status during late-gestation. J. Dev. Physiol., v.19, p.253-261, 1993.
CABRERA, R.A.; LIN, X.; CAMPBELL, J.M.; MOESER, A.J.; ODLE, J. Influence of birth order, birth weight, colostrum and serum immunoglobulin $\mathrm{G}$ on neonatal piglet survival. J. Anim. Sci. Biotechnol., v.3, p.42, 2012.

CALDARA, F.R.; SANTOS, L.S.; MACHADO, S.T.; MOI, M. Piglet's surface temperature change at different weights at birth. Asian-Australas. J. Anim. Sci., v.27, p.431-438, 2014.

CASELLAS, J.; RAUW, W.M.; PIEDRAFITA, J.; SÁNCHEZ, A. et al. Viability of Iberian $\times$ Meishan F2 newborn pigs. I. Analysis of physiological and vitality variables. J. Anim. Sci., v.82, p.1919-1924, 2004.

GONZÁLEZ-LOZANO, M.; MOTA-ROJAS, D.; VELÁZQUEZ-ARMENTA, E.Y. et al. Obstetric and fetal outcomes in dystocic and eutocic sows to an injection of exogenous oxytocin during farrowing. Can. Vet. J., v.50, p.1273-1277, 2009.

GROBAN, L.; ZAPATA-SUDO, G.; LIN, M.; NELSON, T.E. Effects of moderate and deep hypothermia on $\mathrm{Ca} 2+$ signaling in rat ventricular myocytes. Cell Physiol. Biochem., v.12, p.101-110, 2002.

GUNN, A.J.; LAPTOOK, A.R.; ROBERTSON, N.J.; BARKS, J.D. et al. Therapeutic hypothermia translates from ancient history in to practice. Pediatr. Res., v.81, p.202-209, 2017.

HERPIN, P.; LE DIVIDICH, J.; BERTHON, D.; HULIN, J.C. Assessment of thermoregulatory and postprandial thermogenesis over the first 24 hours after birth in pigs. Exp. Physiol., v.79, p.1011-1019, 1994.

HERPIN, P.; LE DIVIDICH, J.; HULIN, J.C.; FILLAUT, M. et al. Effects of the level of asphyxia during delivery on viability at birth and early postnatal vitality of newborn pigs. J. Anim. Sci., v.74, p.20672075, 1996.

HERPIN, P.; DAMON, M.; LE DIVIDICH, J. Development of thermoregulation and neonatal survivalin pigs. Livest. Prod. Sci., v.78, p.25-45, 2002.

IBM SPSS Statistics for Windows. Version 25.0. Armonk, NY: IBM Corp., 2017.

KAMMERSGAARD, T.S.; PEDERSEN, L.J.; JØRGENSEN, E. Hypothermia in neonatal piglets: Interactions and causes of individual differences. $J$. Anim. Sci., v.89, p.2073-2085, 2011.

KÓSA, B.; BÁRDOVÁ, K.; LEŠKOVÁ, L.; REICHEL P. et al. The effect of a feed additive supplemented with porcine plasma protein on growth performance and selected biochemical indices of nursing piglets. Acta Vet. Brno, v.88, p.393-399, 2019. 
LAY JÚNIOR, D.C.; MATTERI, R.L.; CARROLL, J.A.; FRANGMAN, T.J.; SANFRANSKI, T.J. Preweaning survival in swine. J. Anim. Sci., v.80, p.E74-E86, 2002.

MALMKVIST, J.; PEDERSEN, L.J.; KAMMERSGAARD, T.S.; JORGENSEN, E. Influence of thermal environment on sows around farrowing and during the lactation period. J. Anim. Sci., v.90, p.3186-3199, 2012.

MOREIRA, L.P.; MENEGAT, M.B.; BARROS, G.P.; BERNARDI, M.L. et al. Effect of colostrum, and protein and energy supplementation on survival and performance of low-birth weight piglets. Livest. Sci., v.202, p.188-193, 2016.

MARTÍNEZ-RODRÍGUEZ, R.; MOTA-ROJAS, D.; TRUJILLO-ORTEGA, M.E.; OROZCO-GREGORIO, H. et al. Physiological response to hypoxia in piglets of different birth weight. Ital. J. Anim. Sci., v.10, p.e56e59, 2011.

MOTA-ROJAS, D.; FIERRO, R.; ROLDANSANTIAGO, P.; OROZCO-GREGORIO, H. et al. Outcomes of gestation length in relation to farrowing performance in sows and daily weight gain and metabolic profiles in piglets. Anim. Prod. Sci., v.55, p.93-100, 2015.

MUNS, R.; MANZANILLA, E.G.; SOL, C.; MANTECA, X.; GASA, J. Piglet behaviour as a measure of vitality and its influence on piglet survival and growth during lactation. J. Anim. Sci., v.91, p.18381843, 2013.

MUNS, R.; MANTECA, X.; GASA, J. Effect of different management techniques to enhance colostrum intake on piglet's growth and mortality. Anim. Welfare, v.92, p.1193-1199, 2015.

OROZCO-GREGORIO, H.; MOTA-ROJAS, D.; BONILLA-JAIME, H.; TRUJILLO-ORTEGA, M.E. et al Effects of administration of caffeine on metabolic variables in neonatal pigs with peripartum asphyxia. Am. J. Vet. Res., v.71, p.1214-1219, 2010.

PANZARDI, A.; BERNARDI, M.L.; MELLAGI, A.P.; BIERHALS, T. et al. Newborn piglet traits associated with survival and growth performance until weaning. Vet. Med., v.110, p.206-213, 2013.

ROWLAND, L.A.; BAL, N.C.; PERIASAMY, M. The role of skeletalmuscle-based thermogenic mechanisms in vertebrate endothermy. Biol. Rev., v.90, p.12791297,2014
RUTHERFORD, K.M.D.; BAXTER, E.M.; EATH, R.B.; TURNER, S.P. et al. The welfare implications of large litter size in the domestic pig I: biological factors. Anim. Welfare, v.22, p.199-218, 2013.

SAHUQUILLO, J.; VILALTA, A. Cooling the injured brain: how does moderate hypothermia influence the pathophysiology of traumatic brain injury. Curr. Pharm. Des., v.13, p.2310-2322, 2007.

SJAASTAD, Ø.; SAND, O.; HOVE, K. Physiology of domestic animals. 2.ed. Scandinavian: Veterinary Press, 2010.

SOERENSEN, D.D.; PEDERSEN, L.J. Infrared skin temperature measurements for monitoring health in pigs: a review. Acta Vet. Scand., v.57, 5p., 2015.

STAARVIK, T.; FRAMSTAD, T.; HEGGELUND, M.; FREMGAARDEN, S.B.; KIELLAND, C. Bloodglucose levels in newborn piglets and the associations between blood-glucose levels, intrauterine growth restriction and pre-weaning mortality. Porcine Health Manag., v.5, p.3-10, 2019.

STEEN, P.A.; SOULE, E.H.; MICHENFELDER, J.D. Deterimental effect of prolonged hypothermia in cats and monkeys with and without regional cerebral ischemia. Stroke, v.10, p.522-529, 1979.

THEIL, P.K.; LAURIDSEN, C.; QUESNEL, H. Neonatal piglet survival: impact of sow nutrition around parturition on fetal glycogen deposition and production and composition of colostrum and transient milk. Animal, v.8, p.1021-1030, 2014.

TRAYHURN， P.; TEMPLE， N.J.; AERDE，J.V. Evidence from immunoblotting studies on uncoupling protein that brown adipose tissue is not present in the domestic pig. Can. J. Physiol. Pharmacol., v.67, p.1480-1485, 1989.

TRUJILLO-ORTEGA, M.E.; MOTA-ROJAS, D.; OLMOS-HERNÁNDEZ, A.; ALONSO-SPILSBURY, M. et al. A study of piglets born by spontaneous parturition under uncontrolled conditions: could this be a naturalistic model for the study of intrapartum asphyxia? Acta Biomed., v.78, p.29-35, 2007.

TUCHSCHERER, M.; PUPPE, B.; TUCHSCHERER, A.; TIEMANN, U. Early identification of neonates at risk: traits of newborn piglets with respect to survival. Theriogenology, v.54, p.371-388, 2000.

VALLET, J.L.; MILES, J.R. Comparison of myelination between large and small pig fetuses during late gestation. Anim. Reprod. Sci., v.132, p.50-57, 2012. 